\title{
Alternatives for methane emission mitigation in livestock systems
}

\author{
Carlos E. Lascano ${ }^{1}$, Edgar Cárdenas ${ }^{1}$
}

${ }^{1}$ National University of Colombia, Bogotá, Colombia.

ABSTRACT - Human activities are contributing to Global Climate Change through the production of Green House Gases (GHG), which result in increased air, land and ocean temperatures and extreme changes in precipitation in regions of low and high rainfall. The most important GHG's are carbon dioxide $\left(\mathrm{CO}_{2}\right)$, methane $\left(\mathrm{CH}_{4}\right)$ and nitrous oxide $\left(\mathrm{N}_{2} \mathrm{O}\right)$. It is estimated that $18 \%$ of the annual GHG emissions come from different types of livestock and that $37 \%$ of $\mathrm{CH}_{4}$, with higher global warming potential (23) relative to $\mathrm{CO}_{2}$ (1), comes from fermentation processes in ruminants. It is possible that in the future beef and milk exports from producing countries is subject to bans if cattle systems do not comply with measures to reduce GHG. There are several alternatives available and being researched to reduce enteric $\mathrm{CH}_{4}$ emissions from cattle that range from manipulating diet composition, supplementing feed additives (i.e. ionophores, organic acids, halogenated compounds, oils) and selection of forage plants of high quality and containing secondary metabolites (i.e. tannins and saponins) to animal breeding, immunization and genetic transformation of rumen microorganisms. Results show that inhibition of enteric $\mathrm{CH}_{4}$ emission is possible through the use of ionophores, organic acids and oils. The use of ionophores can result in resistance of rumen microbes and as a result the effect is short term. The high cost of organic acids makes it unlikely that there direct supplementation in ruminant diets is economically viable. However, organic acids are present at relatively high concentrations in the leaf tissue of plants and attempts should be made to select and breed forages with higher levels of these compounds. It is argued that a more efficient strategy to reduce enteric $\mathrm{CH}_{4}$ in ruminants is through selection of grasses of high quality (i.e. high concentration of water soluble carbohydrates), of forage legumes containing secondary metabolites like tannins and of fruits/plants containing saponins, provided that they do not affect intake and digestibility. Improved nutrition of cattle through feeding high quality forages can result in high animal performance and in reductions of $\mathrm{CH}_{4}$ emitted per unit of dry matter intake and per unit of product.

Key Words: climate change, defaunation, feed chemical additives, genetic transformation of bacteria, greenhouse gases, immunization, saponins, tannins

\section{Alternativas para mitigação de emissão de metano em sistemas de criação de animais domésticos}

RESUMO - As atividades humanas têm contribuído para a mudança do clima global, pela produção de gases de efeito estufa, dos quais podem resultar no aumento da temperatura atmosférica e mudanças extremas de precipitação em regiões de altas e baixas pluviosidades. Os gases de efeito estufa mais importantes são o dióxido de carbono $\left(\mathrm{CO}_{2}\right)$, o metano $\left(\mathrm{CH}_{4}\right)$ e o óxido nitroso $\left(\mathrm{N}_{2} \mathrm{O}\right)$. Estima-se que $18 \%$ das emissões anuais de GEE são provenientes de diferentes tipos de animais e que $37 \%$ do $\mathrm{CH}_{4}$, com maior potencial de aquecimento global (23) em relação ao $\mathrm{CO}_{2}$ (1), decorrem dos processos fermentativos dos ruminantes. Possivelmente, no futuro, os países produtores de carne e leite estarão sujeitos a proibições, caso os sistemas de bovinocultura não cumpram as medidas de redução de gases de efeito estufa. Há diversas alternativas disponíveis e em estudo para reduzir as emissões de $\mathrm{CH}_{4}$ entérica de bovinos, que vão desde a manipulação da composição da dieta, suplementação com aditivos (ionóforos, ácidos orgânicos, compostos halogênios, óleos) e seleção de plantas forrageiras de alta qualidade contendo metabólitos secundários (taninos e saponinas) ao melhoramento animal, imunização e transformação genética dos microrganismos ruminais. Os resultados mostram que é possível a inibição da emissão entérica de $\mathrm{CH}_{4}$ utilizando-se ionóforos, ácidos orgânicos e óleos. O uso de ionóforos pode resultar em resistência dos microorganimos ruminais e, como resultado, o efeito é de curta duração. O custo elevado dos ácidos orgânicos torna-os economicamente inviáveis se adicionados diretamente na dieta de ruminantes. No entanto, os ácidos orgânicos estão presentes em concentrações relativamente elevadas no tecido foliar das plantas, e devem ser feitas tentativas para selecionar e produzir forragens com altos níveis destes compostos. Argumenta-se que uma estratégia mais eficiente para redução entérica de $\mathrm{CH}_{4}$ em ruminantes seja com a escolha de forragens de alta qualidade (alta concentração de carboidratos solúveis), de leguminosas contendo metabólitos secundários como taninos e de frutos e/ou plantas contendo saponinas, desde que estes não afetem o consumo e a digestibilidade. Melhora da nutrição de bovinos por meio da alimentação com forrageiras de alta qualidade pode resultar em bom desempenho dos animais e na redução da emissão de $\mathrm{CH}_{4}$ por unidade de consumo de matéria seca e por unidade de produto.

Palavras-chave: aditivos químicos dos alimentos, defaunação, gases de efeito estufa, imunização, mudança climática, saponinas, taninos, transformação genética de bactérias

Corresponding author:c.lascano@cgiar.org; eacardenasr@unal.edu.co 


\section{Introduction}

The Intergovernmental Panel on Climate Change (IPCC), convened by the United Nations, has reported evidence that human activities over the past 50 years have influenced Global Climate through the production of Green House Gases (GHG), which results in increased absorption in the atmosphere of infrared radiations emitted from the earth's surface. The accumulation of GHG results in increased global temperature (approximately 0.6 to $0.7^{\circ} \mathrm{C}$ ), which in turn can increase annual precipitation in high rainfall regions and decrease precipitation in regions of low rainfall (Gerstengarbe \& Werner, 2008). The most important GHG's are carbon dioxide $\left(\mathrm{CO}_{2}\right)$, methane $\left(\mathrm{CH}_{4}\right)$ and nitrous oxide $\left(\mathrm{N}_{2} \mathrm{O}\right)$, which have increased in the last 150 years (Monteny et al., 2006) and have different global warming potential. According to Ramaswany et al. (2001) and Solomon et al. (2007), the warming potential of $\mathrm{CO}_{2}, \mathrm{CH}_{4}$ and $\mathrm{N}_{2} \mathrm{O}$ is 1,23 , and 298, respectively. Burning of fossil fuels is the main source of $\mathrm{CO}_{2}$ emissions, while agriculture activities are the main contributors of global emissions of $\mathrm{CH}_{4}$ and $\mathrm{N}_{2} \mathrm{O}$ (Wheeler et al., 2008). Thus, adoption of agricultural practices and technologies aimed specifically at reducing emissions from this sector will have a significant impact on total GHG emissions.

Livestock are well-known to contribute to GHG emissions. In the widely - cited 2006 report (Livestock's Long Shadow) by the United Nations Food and Agriculture Organization (FAO), it is indicated that $18 \%$ of annual worldwide GHG emissions, are attributable to cattle, buffalo, sheep, goats, camels, horses, pigs, and poultry. Agriculture and in particular enteric fermentation in ruminants (predominantly cattle and sheep) produces between 21 and $25 \%$ of the total anthropogenic emissions of $\mathrm{CH}_{4}$ on a global scale. The two major sources of agricultural $\mathrm{CH}_{4}$ emissions are enteric fermentation in ruminants and livestock manure. In this paper we will focus on enteric $\mathrm{CH}_{4}$.

Many countries with large cattle populations are signatory to the Kyoto Protocol Framework Convention on Climate Change (1997), which requires that signatory countries maintain greenhouse gas emissions at 1990 levels by 2012. A non binding agreement was reached in Copenhagen (2009) by which 25 countries agreed to reduce GHG by $50 \%$ in 2050 in order to prevent that global temperature increased more than $2^{\circ} \mathrm{C}$.

It is conceivable that if a carbon tax for greenhouse gas emissions is introduced as part of an agreement among countries to reduce GHG emissions, the cattle industry in many countries stands to lose profits. In addition, it is possible that beef and milk exports from producing countries are subject to bans if cattle systems do not comply with measures to reduce GHG. Hence the need to investigate how we can reduce $\mathrm{CH}_{4}$ emissions from ruminants should be of high priority in cattle producing countries.

In this paper we review alternatives to reduce $\mathrm{CH}_{4}$ emissions from cattle through the use feed additives and of forage plants and fruits containing secondary metabolites. Mechanism of enteric methane production in ruminants

The major factors influencing $\mathrm{CH}_{4}$ emissions from ruminants are: a) level of feed intake, b) type of carbohydrate fed and c) alteration of the ruminal microflora (Johnson \& Johnson, 1995). Feed consumed by cattle is fermented in the rumen by bacteria, protozoa, and fungi and as a result polysaccharides in the feed are converted into volatile fatty acids (VFA) and microbial protein accompanied by the release of gaseous by-products (carbon dioxide and hydrogen) (Kamra, 2005). In adult cattle molecular hydrogen is produced every day, which does not accumulate as gases in the rumen given the presence of methanogenic archaea and other hydrogen utilizing microbes in the rumen. The symbiosis between bacteria that ferment polysaccharides and produce hydrogen and the methanogens which utilize hydrogen to reduce $\mathrm{CO}_{2}$ and produce $\mathrm{CH}_{4}$ results in an enhanced digestion of feed and microbial biomass production. As a result of this process, ruminants' loose between $2-12 \%$ of the gross dietary energy in the form of $\mathrm{CH}_{4}$, depending on the quality and quantity of diet offered and consumed (Johnson \& Johnson, 1995). Approximately $87 \%$ of the enteric $\mathrm{CH}_{4}$ is produced in the rumen and the remaining $13 \%$ is released in the large intestine through fermentation (Lockyer \& Jarvis 1995; Lassey et al., 1997)

In summary, methane produced by cattle (250-500 l/ day) not only affects the efficiency of energy utilization by ruminants, but also contribute significantly to environmental pollution. Thus it is essential to look for alternatives to reduce $\mathrm{CH}_{4}$ emissions in cattle and by doing so contribute to less GHG and at the same time improve feed conversion efficiency, which should translate into economical profits for producers.

Strategies to reduce enteric methane emissions from ruminants

Different strategies available to reduce $\mathrm{CH}_{4}$ emission from enteric fermentation were reviewed by Hopkins \& Del Prado (2007). They categorize them as: dietary changes, direct rumen manipulation and systematic changes. The latter include considerations of breed, livestock numbers and intensiveness of production. More intensive production may result in lower $\mathrm{CH}_{4}$ emission, but may be less desirable in terms of other environmental impacts. 
An overall reduction in $\mathrm{CH}_{4}$ production (liters/day) per individual animal is the ideal goal. However, given the nature of livestock production systems, the immediate goal should be to reduce $\mathrm{CH}_{4}$ per unit of product (milk or beef). Decreasing livestock numbers as an approach to reducing $\mathrm{CH}_{4}$ implies reducing numbers, but holding productivity per animal constant so that $\mathrm{CH}_{4}$ emissions fall. This strategy has economic consequences as the profit from livestock farms will decline in direct proportion to the reduction in numbers of animals. As milk or beef production per animal increases, $\mathrm{CH}_{4}$ output per animal also increases, but both the proportion of gross energy used in the production of $\mathrm{CH}_{4}$ and the amount of $\mathrm{CH}_{4}$ emitted to produce a given quantity of milk or beef falls (Blaxter \& Clapperton, 1965).

In summary, improvements in the efficiency of conversion of feed into animal product will reduce the amount of $\mathrm{CH}_{4}$ emitted per unit of product, but will not necessarily reduce the amount of $\mathrm{CH}_{4}$ produced in total.

In what follows we summarize feeding strategies and use of feed additive that have been evaluated to reduce $\mathrm{CH}_{4}$ in ruminants and will highlight some areas of research that could be considered promising to reduce enteric $\mathrm{CH}_{4}$.

Alternative feeding strategies to reduce methane in ruminants

\section{Manipulating nutrient composition of the diet}

Manipulating the nutrient composition of the diet of ruminants can directly reduce enteric $\mathrm{CH}_{4}$ output. For example, a high proportion of concentrates (grain based feeds) in the diet tends to reduce the protozoa population in the rumen, reduce rumen $\mathrm{pH}$, alter the acetate: propionate ratio and decrease the amount of $\mathrm{CH}_{4}$ produced per unit of feed intake (Blaxter \& Clapperton, 1965). The proportion of concentrates in the diet needed to bring about this effect may well be over 50\%. The direct manipulations of the diet in pasture - based systems by feeding concentrate supplements has economical consequences, which limit their use in many cattle production systems. Developing forages that directly reduce $\mathrm{CH}_{4}$ is likely to be a better option for reducing $\mathrm{CH}_{4}$ than feed supplementation based on concentrates.

\section{Selection of plants with secondary compounds}

In many studies (in vitro and in vivo) it has been demonstrated that with temperate legumes (Hedysarium coronarium, Lespedeza cuneata, Lotus corniculatus and L. uliginosus) and tropical legumes (Calliandra calothyrsus, Flemingia macrophylla) that contain secondary compounds such as condensed tannins (CT) it is possible to reduce methanogenesis. Tannins and phenolic monomers have been found to be toxic for some of the rumen microbes, especially ciliate protozoa, fiber degrading bacteria and methanogenic archaea, and as a result methanogenesis in the rumen can also be reduced. However, Tiemann et al. (2008) indicated that with some tropical legumes with tannins (i.e. Calliandra calothyrsus and Fleminigia macrophylla) there low fiber digestibility also contributes to the reduced in vitro $\mathrm{CH}_{4}$ production measured with these legumes.

Reports in the literature provide evidence that by feeding legumes with $\mathrm{CT}$ there is a reduction of $\mathrm{CH}_{4}$ production in different ruminant animals. In a review by Ramirez-Restrepo \& Barry (2005) on alternative forages containing secondary compounds for improving sustainable production of grazing ruminants, they indicated that the condensed tannincontaining legumes Lotus corniculatus and sulla (Hedysarum coronarium) promoted faster growth rates in young sheep and deer in the presence of internal parasites, and showed reduced methane production relative to forages without tannins (Chicorium intybus). They also reported that grazing on L. corniculatus with CT was associated with increases in reproductive rate in sheep, increases in milk production in both ewes and dairy cows and reduced $\mathrm{CH}_{4}$ production.

In other studies, Lotus pedunculatus was compared with ryegrass silage diets in Holstein cows and results showed that production of $\mathrm{CH}_{4}$ was 27 and 35 per kg of dry matter intake for Lotus and silage ryegrass, respectively (Woodward et al., 2001). In a study carried out with sheep Carulla et al. (2005), found that the addition of Acacia mearnsii with CT to diets of Lolium perenne reduced by $13 \%$ the emissions of $\mathrm{CH}_{4}$. In goats consuming different levels of CT from Lespedeza striata there was a reduction in the emission of $\mathrm{CH}_{4}$, while in the same study feeding Sorghum bicolor with lower levels of CT showed no reduction of enteric production o $\mathrm{CH}_{4}$ (Animut et al., 2008).

Studies reported in the literature on strategic use of tropical legumes with tannins to reduce $\mathrm{CH}_{4}$ in ruminants are limited. Hess et al. (2006) reported reductions in $\mathrm{CH}_{4}$ emissions when feeding Calliandra calothyrsus high in tannins as compared to Cratylia argentea low in tannins.

In summary, experimental evidence with temperate and to a lesser extent with tropical plants suggests that by using legume species with tannins it is possible to decrease the amount of enteric $\mathrm{CH}_{4}$ produced by ruminants. It should be kept in mind that the methanogenic effect produced is not the same for all CT, but rather depends on the concentration and structure of the CT being fed (Min et al., 2003). Finally, the impact of legume forages with $\mathrm{CT}$ to reduce $\mathrm{CH}_{4}$ could be constrained by the area sown each year in livestock producing regions of the world. 
Oils

Vegetable and animal oils have been used in ruminant rations to increase the energy density of diets. However, the use of oils $t$ is considered by some as very promising dietary alternatives to depress ruminal methanogenesis. It has been shown that vegetable oils can decrease $\mathrm{CH}_{4}$ production in vitro (Broudiscou \& Lassalas, 1991) as well as in vivo in sheep at maintenance (Czerkawski et al., 1966), in growing lambs (Machmüller et al., 2000) and in dairy cattle (Martin et al., 2008). Other studies have reported a 27\% reduction in $\mathrm{CH}_{4}$ emission with the supplementation of fish oil and sunflower oil in quantities of $500 \mathrm{mg} / \mathrm{d}$ when fed to dairy cows in short periods (14 days) (Woodward et al., 2006). However, when these same oils were fed for longer periods of time (12 weeks) there was no reduction of $\mathrm{CH}_{4}$.

The reduction in methanogesis with oils/lipids appears to be the result of inhibition of microbial flora especially protozoa (Hu et al., 2005). Recent studies by Mao et al. (2010) showed a direct effect of soybean oil on reduction of protozoa and ruminal $\mathrm{CH}_{4}$ production in sheep. The addition of coconut oil to forage and concentrate rations supplemented to Charolais steers showed a reduction in voluntary intake and protozoa population and this was reflected in low $\mathrm{CH}_{4}$ emissions, without affecting livestock production (Lovett et al., 2003).

In summary, from the results reviewed it is evident that vegetable and animal oils are a good alternative to reduce $\mathrm{CH}_{4}$, but it is not clear if this reduction is long or short term. It is also not well defined if the effect of oils on methanogenesis is due to reduced intake, to the inhibiting effect of oils on protozoa or on the reduction of digestion of dietary fiber.

\section{Ionophores}

Antibiotics that are used as feed additive and that affect several pathways of fermentation in ruminants. Among, the ionospheres, monensin is the most studied in ruminants, although other such as lasalocid, salinomycin, nigercin and gramicidin are also available. When added to the diet, ionophores affect $\mathrm{CH}_{4}$ production in two ways: a) increased feed conversion efficiency and this reduces $\mathrm{CH}_{4}$ output per unit of product and b) reduced amount of $\mathrm{CH}_{4}$ produced per unit of dry matter consumed because of their effect on rumen fermentation.

In relation to feed conversion efficiency, a common result is that ionophores reduce intake but maintain or increase animal productivity. On high concentrate diets, results from a number of trials indicates that dry matter intake can be reduced by $5-6 \%$ and feed conversion efficiency increased by 6-7\% (van Nevel \& Demayer, 1996;
Raun et al., 1976; Goodrich et al., 1984). Less data is available on the effects of ionophores on forage based diets and the results tend to be more variable (O’Kelly \& Spiers, 1992). Herbage intake has been measured less frequently on forage diets, but is usually unaffected or reduced when ionophores are supplemented (O’Kelly \& Spiers, 1992).

In a review of in-vitro studies, van Nevel \& Demayer (1996) found that ionophores reduce $\mathrm{CH}_{4}$ output, but the percentage inhibition showed a wide range $(0-76 \%)$ and this seem to be related to ionophore type and dose rate. The same authors give a figure of $18 \%$ as average reduction of enteric $\mathrm{CH}_{4}$ emissions from in-vivo trials. In other studies, O’Kelly \& Spiers (1992) working with steers fed Lucerne found that $55 \%$ of the reduction in $\mathrm{CH}_{4}$ due to supplementation of ionophores was related to reduced intake and $45 \%$ to direct effect on rumen fermentation. One concern from some in-vivo trials is evidence of adaptation of rumen microorganisms to ionophores in a way that enteric $\mathrm{CH}_{4}$ reduction per unit of feed is short term (Johnson \& Johnson, 1995).

In general, due to the dual impact (reduced intake and changes in rumen fermentation patterns) of ionophores on enteric $\mathrm{CH}_{4}$ production, the feeding of ionophore is an alternative for reducing $\mathrm{CH}_{4}$. However, studies with grazing ruminants need to be carried to confirm the utility and short or long term effects of ionophores for reducing enteric $\mathrm{CH}_{4}$. Of particular concern is that ionophores could accumulate in animal products, that rumen bacteria could get adapted to the antibiotic and that they need to be fed at frequent daily intervals unless they can be delivered by a slow release delivery device.

\section{Probiotics}

Are microbial feed additives that have been developed to improve animal productivity by directly influencing rumen fermentation. Wallace \& Newbold (1993) reviewed data from trials involving dairy cows and growing cattle fed high concentrate diets and calculated that probiotics improved productivity by $7-8 \%$. Interest in probiotics as a potential technology to reduce $\mathrm{CH}_{4}$ came from findings that in vitro they can directly reduce $\mathrm{CH}_{4}$ production (Frumholtz et al., 1989). However, in vitro results on $\mathrm{CH}_{4}$ reduction have not been consistent (Martin et al., 1989) and there are no reports in the literature on in vivo $\mathrm{CH}_{4}$ production after supplementation of probiotics.

Given that probiotics are feed additives that need to be fed daily, they would appear to be only suitable for systems where feed supplements are given on a routine basis or for lactating dairy cows. This combined with the limited evidence that probiotics directly influence $\mathrm{CH}_{4}$ 
emissions indicate that they have limited utility to reduce $\mathrm{CH}_{4}$ in ruminants.

\section{Organic acids}

As indicated earlier, enteric $\mathrm{CH}_{4}$ arises from the conversion of hydrogen to $\mathrm{CH}_{4}$ by a specific group of micro organisms, collectively described as methanogens. Other microorganisms break down feed to produce VFA, carbon dioxide and hydrogen. Increasing the production of one of these fatty acids (propionate) reduces hydrogen production, resulting in less being available for conversion to $\mathrm{CH}_{4}$. A number of organic acids (malate, fumarate, and pyruvate) are needed as precursors to propionate and if the rumen concentrations of these acids could be increased, propionate production would increase and methane production would fall. Malate is the organic acid most studied in relation to $\mathrm{CH}_{4}$ production although fumarate has also been the subject of some limited work.

In vitro studies conducted by Martin \& Streeter (1995) demonstrated that malate increases propionate production and decreases $\mathrm{CH}_{4}$ output. The same workers (Martin et al., 1999) also found that direct supplementation of malate to the diet of finishing steers improved feed conversion efficiency. No reports were found in the literature of studies where $\mathrm{CH}_{4}$ output has been measured from ruminants receiving malate supplementation. Other organic acids such fumarate has not been shown to decrease $\mathrm{CH}_{4}$ production in vivo (Beauchemin \& McGinn, 2006).

The high cost of organic acids makes it unlikely that direct supplementation of ruminant diets is an economic proposition. However, organic acids are present at relatively high concentrations in the leaf tissue of plants and it may be possible to select and breed forages with higher levels of these compounds. Studies from the USA with Lucerne, Bermuda grass and Tall Fescue indicate that concentrations of organic acids vary among species and cultivars of the same species (Callaway et al., 1997). However, from the information available in the literature it is not possible to conclude if differences in organic acid concentrations found among forage species and cultivars are large enough to influence $\mathrm{CH}_{4}$ production by ruminants.

\section{Halogenated compounds}

Chemical products such as bromochloromethane are potentially strong inhibitors of $\mathrm{CH}_{4}$ production in ruminants. For example, when added to ruminant diets at a rate of $5 \mathrm{~g}$ per day, bromochloromethane was shown to reduce $\mathrm{CH}_{4}$ for up to 15 hours after treatment (McCrabb et al., 1997). In addition to reducing $\mathrm{CH}_{4}$ these compounds reduce intake and have little effect on live weight gain, which results in increased feed conversion efficiency (McCrabb, 2000).
In Australia, a compound containing bromochloromethane and cyclodextrin has been found to have a very large impact on enteric $\mathrm{CH}_{4}$ production (May et al., 1995). When fed to cattle at hourly intervals it completely reduced $\mathrm{CH}_{4}$ production (McCrabb et al., 1997) and when fed twice daily to cattle over an eight week period, it reduced $\mathrm{CH}_{4}$ output by 54\% (McCrabb, 2000).

A potential problem with halogenated compounds is that microbial populations may adapt and as result $\mathrm{CH}_{4}$ inhibition may be short term (van Nevel and Demeyer 1996). They are also unstable compounds which are potentially toxic to ruminants and humans. Much more work needs to be done to define the utility of halogenated compounds as a $\mathrm{CH}_{4}$ mitigation tool.

Other alternatives being researched to reduce methane emissions from cattle

\section{Animal breeding and selection}

There is plenty of evidence that indicates that improving individual animal performance reduces $\mathrm{CH}_{4}$ produced per unit of product. It is also possible that some animals have intrinsic lower $\mathrm{CH}_{4}$ emissions per unit of intake than others at the same level of performance. In trials with grazing sheep, Pinares-Patiño et al. (2003) identified some animals as 'high' and 'low' emitters per unit of feed intake in a single trial and then confirmed in a second trial that these differences persisted when the same type of diet was fed. The reasons why particular animals emitted less $\mathrm{CH}_{4}$ per unit of feed intake in these trials is not known, but it does raise the possibility of genetic differences between animals in $\mathrm{CH}_{4}$ production. Breeding animals with higher levels of individual performance will counteract the adverse consequences for $\mathrm{CH}_{4}$ production resulting from increases in cattle numbers in livestock producing regions.

Other researcher have indicated that selection of animals with low potential to emit $\mathrm{CH}_{4}$ should be based on differences in the gastrointestinal tract (i.e. feed retention time), which has an effect on digestion. For example, Waghorn et al. (2006) reported that when compared at the same stages of lactation (60 and 150 days), Holstein cows from the Northern Hemisphere consuming mixed diets produced $15 \%$ less $\mathrm{CH} 4 / \mathrm{kg}$ of dry matter intake than cows from New Zealand also consuming mixed diets. However, in a recent study Munger \& Kreuzer (2008) compared the emission of $\mathrm{CH}_{4}$ in Jersey and Simmental cattle fed ad libitum in open gas exchange chamber and found no differences in $\mathrm{CH}_{4}$ production between breeds. 


\section{Defaunation}

The elimination of protozoa from the rumen has been shown to reduce the amount of enteric $\mathrm{CH}_{4}$ produced in a number of ways: a) lowered fiber digestion, b) reduced methanogen populations that are symbiotically associated with protozoa and c) reduced hydrogen production (Hegarty, 1999).

It is well documented that the secondary compounds known as saponins have antiprotozoal activity, but the level of antiprotozoal activity may vary with the type of saponin (Hess et al., 2003). In the rumen, methanogens are associated with protozoa (Lange et al., 2005), thus any additive which reduces the protozoa population will inhibit $\mathrm{CH}_{4}$ production indirectly.

In vitro studies carried out in India using extracts of Sapindus mukorossi (a seed rich in saponins) showed a $52 \%$ reduction in protozoa population when ethanol extract was added in the incubation medium and this was associated with $96 \%$ inhibition in $\mathrm{CH}_{4}$ production by rumen microbes of buffalos (Agarwal et al., 2009). One drawback was that this extract also reduced in vitro feed degradability by 48\%. In other studies, Abreu et al. (2004) observed that with the addition of the saponin -rich fruit fruit $S$. saponaria in the diet of sheep fed a low quality grass there was an increase in propionate relative to acetate, but without affecting the protozoa population. Hess et al. (2003) also evaluated in vitro the fruit of $S$. saponaria and found decreased protozoal count (by 54\%) and daily $\mathrm{CH}_{4}$ release (by 20\%) relative to the control (grass + legume hay + straw + urea), but without affecting the methanogen count. In this study defaunation suppressed methanogenesis by $43 \%$ over all and the effect of $S$. saponaria on $\mathrm{CH}_{4}$ was greater in defaunated (29\%) than in faunated rumen fluid (14\%).

In general, there is evidence that saponins from tropical fruits suppress the protozoa population and by doing so reduce methanogenesis, but the effect would not seem to be exclusively due to protozoal count depression. It would also appear that for practical use of Sapindus spp. as a feed additive to control enteric $\mathrm{CH}_{4}$ emission there is a need to standardize a dose based on saponin type and concentration in order to achieve maximum inhibition in $\mathrm{CH}_{4}$ production with minimum adverse effect on feed utilization and animal performance.

\section{Immunization}

A team of researchers in Western Australia have taken out two patents on a vaccine that is claimed to improve animal performance and directly reduce $\mathrm{CH}_{4}$ by invoking an immune response in the rumen to protozoa and methanogens. Details in the scientific literature on the product are not available, but publicity material available from CSIRO (http://www.csiro.gov.au), claims that based on animal trials in sheep it will reduce methane production in sheep and cattle by 11 - 23\% and, in addition, increase animal productivity. However, some authors have considered that the anti-methanogen activity of antibodies present in a vaccine for reducing methane in ruminants could be of short term nature given that proteolitic degradation in the rumen could limit their persistence (Li et al., 2007; Cook et al., 2008).

The vaccine is still at the development stage and if proven successful it will not likely be commercially available in the near future.

\section{Acetogens}

These are bacteria present in adult ruminants that produce acetic acid by the reduction of $\mathrm{CO}_{2}$ with hydrogen in the rumen. Although acetogenic bacteria can utilize $\mathrm{H}_{2}$ and $\mathrm{CO}_{2}$ to form acetate in the rumen, even large concentrations of acetogenic bacteria cannot compete for $\mathrm{H}_{2}$ with methanogenic archaea under normal circumstances (Lopez et al., 1999).

In general, research carried out in Europe is attempting to increase the populations of acetogenic bacteria at the expense of methanogenic bacteria. If this approach is successful it would reduce $\mathrm{CH}_{4}$ and increase the efficiency of production since acetic acid is an important energy source for ruminants. The research is at a very early stage and it is not possible to assess how successful this approach will be to reduce $\mathrm{CH}_{4}$.

\section{Genetic transformation of bacteria}

Altering the fermentation characteristics of rumen microorganisms by genetic modification was identified as a mechanism whereby ruminant $\mathrm{CH}_{4}$ emissions could be reduced (Armstrong \& Gilbert, 1985). Research is at an early stage and has so far concentrated on the use of molecular biology techniques to quantify and characterize rumen microbial populations (Greg et al., 1996).

Many of the persistent doubts about rumen bacterial genetic manipulation and the viability of altered organisms in a competitive environment have been shown to be capable of resolution. In addition, the technology now available will allow extensive characterization of the molecular genetics of rumen bacteria with a precision that was not previously possible. However, it should be kept in mind that even if genetically altered rumen microbes did become available their acceptance by both producers and consumers is debatable. The approval of any 
product/organism would have to meet both national and international regulatory standards for GM organisms and products.

\section{Conclusions}

The inhibition of enteric $\mathrm{CH}_{4}$ emission in ruminant animals is possible through the use of vegetable and animal oils, chemical feed additives like organic acids or antibiotics (ionophores), but high cost and/or short term nature of their effects may limit their use. Therefore, it would seem that efforts should be made to select feed ingredients and to identify forage plants containing secondary metabolites (tannins and saponins) that can be used to inhibit methanogenesis selectively, but without adversely affecting feed utilization. Genetic differences between animals in $\mathrm{CH}_{4}$ production should also be explored in current animal breeding programs in the tropics.

There is evidence that shows that improved grass cultivars can increase animal performance without changing the quantity of feed consumed (Woodfield \& Easton, 2004). This would imply a reduction in $\mathrm{CH}_{4}$ production per unit of product and per animal. One option that should be explored is the development through breeding of tropical grass cultivars containing high levels of water soluble carbohydrates to increase animal performance and reduce $\mathrm{CH}_{4}$ per animal as has been shown with ryegrass genotypes in the UK (Lovett et al., 2006). The potential for $\mathrm{CH}_{4}$ mitigation through the genetic improvement of forage species remains largely unexplored and has been the subject of a review recently published by the FAO (2007) entitled "The genetic improvement of forage grasses and legumes to reduce greenhouse gas emissions”.

In summary, the range of technical options available at present to farmers to reduce $\mathrm{CH}_{4}$ emissions in cattle is limited and no single option appears to provide a simple solution. However, selection and breeding of animals with low capacity to produce $\mathrm{CH} 4$, selection and utilization of high quality forages, strategic supplementation forages with tannins, and better management of livestock in pasturebased systems are options that should be considered for reducing enteric $\mathrm{CH}_{4}$ emitted per animal and per unit of product.

\section{References}

ABREU, A.; CARULlA, J.E.; LASCANO, C.E. et al. Effects of Sapindus saponaria fruits on ruminal fermentation and duodenal nitrogen flow of sheep fed a tropical grass diet with and without legume. Journal of Animal Science, v.82, p.1392-1400, 2004.
AGARWAL, N.; SHEKHAR, C.; KUMAR, R. et. al. Effect of peppermint (Mentha piperita) oil on in vitro methanogenesis and fermentation of feed with buffalo rumen liquor. Animal Science and Technology, v.148, p.321-327, 2009.

ANIMUT, G.; PUCHALA, R.; GOETSH, A.L. et al. Methane emission by goats consuming diets with different levels of condensed tannins from lespedeza. Animal Feed Science and Technology, v.144, p.212-227, 2008.

ARMSTRONG, D.G.; GILBERT, H.J. Biotechnology and the rumen: a mini review. Journal of the Science of Food and Agriculture, v.36, p.1039-1046, 1985.

BEAUCHEMIN, K.A.; McGINN, S.M. Methane emissions from beef cattle: effects of fumaric acid, essential oil, and canola oil. Journal of Animal Science, v.84, p.1489-1496, 2006.

BLAXTER, K.L.; CLAPPERTON, J.L. Prediction of the amount of methane produced by ruminants. British Journal of Nutrition, v.19, p.511-522, 1965

BROUDISCOU, L.; LASSALAS, B. Linseed oil supplementation of the diet of sheep: effect on the in vitro fermentation of amino acids and proteins by rumen microorganisms. Animal Feed Science and Technology, v.33, p.161-171, 1991.

CALLAWAY, R.; MARTIN, S.A.; WAMPLER, J.L. et al. Malate content of forage varieties commonly fed to cattle. Journal of Dairy Science, v.80, p.1651-1655, 1997.

CARULLA, J.E.; KREUZER, M.; MACHMÜLLER, A. et al. Supplementation of Acacia mearnsii tannins decreases methanogenesis and urinary nitrogen in forage-fed sheep. Australian Journal of Agriculture Research, v.56, p.961 $-970,2005$

COOK, S.R.; MAITI, P.K.; CHAVES, A.V. et al. Avian (IgY) antimethanogen antibodies for reducing ruminal methane production: in vitro assessment of their effects. Australian Journal of Experimental Agriculture, v.48, p.260-264, 2008.

CZERKAWSKI, J.W.; BLAXTER, K.L.; WAINMAN, F.W. The metabolism of oleic, linoléic and linolenic acids by sheep with reference to their effects on methane production. Brithish Journal of Nutrition, v.20, p.349-362, 1966.

FAO. [2007]. The genetic improvement of forage grasses and legumes to reduce greenhouse gas emissions. Disponível em: http: <(www.fao.org/ag/AGP/.../abberton_\%20genetic improvement.pdf) $>$

GERSTENGARBE, F.W.; WERNER, P. Climate development in the last Century - Global regional. International Journal of Medical Microbiology, v.298, p.5-11, 2008.

FRUMHOLTZ, P.P.; NEWBOLD, C.J.; WALLACE, R.J. Influence of Aspergillus oryzae fermentation extract on the fermentation of a basal ration in the rumen simulation technique (Rusitec). Journal of Agriculture Science, v.113, p.169, 1989.

GOODRICH, R.; GARRETT, J.; GAST, D. et al. Influence of monensin on the performance of cattle. Journal of Animal Science, v.58, p.1484-1498, 1984.

GREG, K.; ALLEN, G.; BEARD, C. Genetic manipulation of rumen bacteria: from potential to reality. Australian Journal of Agricultural Research, v.47, p.247-256, 1996.

HEGARTY, R. Reducing rumen methane emissions through elimination of rumen protozoa. Australian Journal of Agricultural Research, v.50, p.1321-1328, 1999.

HESS, H.D.; KREUZER, M.; DIAZ, T. et al. A. Saponin rich tropical fruits affect fermentation and methanogenesis in faunated and defaunated rumen fluid. Animal Feed Science and Technology, v.109, p.79-94, 2003.

HESS, H.D.; TIEMANN, T.T.; NOTYO, F. et al. Strategic use of tannins as means to limit methane emission from ruminant livestock. International Congress Series, v.1293, p.164167, 2006.

HOPKINS, A.; DEL PRADO, A. Implications of climate change for grasslands in Europe, impacts, adaptations and mitigation options: a review. Grass and Forage Science, v.62, p.118-126, 2007. 
HU, W.; LIU, J.; YE, J. et al. Effect of tea saponin on rumen fermentation in vitro. Animal Feed Science and Technology, v.120, p.333-339, 2005.

JOHNSON, K.A.; JOHNSON, D.E. Methane emissions from cattle. Journal of Animal Science, v.73 p.2483-2492, 1995.

KAMRA, D.N. Rumen microbial ecosystem. Current Science, v.89, p.124-135, 2005.

LANGE, M.; WeStermAnN, P.; AHRING, B.K. Archea in protozoa and metazoan. Applied Microbiology and Biotechnology, v.66, p.465-474, 2005.

LASSEY, K.R.; MARCUS, J.; ULYATT, J. et al. Methane emissions measured directly from grazing livestock in New Zealand. Atmospheric Environment, v.31, p.2905-2914, 1997.

LI, X.; MCALLISTER, T.A.; STANFORD, K. et al. Chitosanalginate microcapsules for oral delivery of egg yolk immunoglobulin (IgY). Journal of Agricultural and Food Chemistry, v.55, p.2911-2917, 2007.

LOCKYER, D.R.; JARVIS, S.C. The measurement of methane losses from grazing animals. Environmental Pollution, v.9, p.383390, 1995.

LOPEZ S.F.; MCINTOSH, M.; WALLACE, R.J. et al. Effect of adding acetogenic bacteria on methane production by mixed rumen microorganisms. Animal Feed Science and Technology, v.78, p.1-9, 1999.

LOVETT, D.; LOVELL, L.; STACK, L. et al. Effect of forage/ concentrate ratio and dietary coconut oil level on methane output and performance of finishing beef heifers. Livestock Production Science, v.84, p.135-146, 2003.

LOVETT, D.K.; MCGILLOWAY, D.; BORTOLOZZO, A. et al. In vitro fermentation patterns and methane production as influenced by cultivar and season of harvest of Lolium perenne L. Grass and Forage Science, v.61, p.9-21, 2006.

MACHMÜLlER, A.; OSSOWSKI, D.A.; KREUZER, M. Comparative evaluation of the effects of coconut oil, oilseeds and crystalline fat on methane release, digestion and energy balance in lambs. Animal. Feed Science and Technology, v.85, p.41-60, 2000.

MAO, H.; WANG, J.; ZHOU, Y. et al. Effects of addition of tea saponins and soybean oil on methane production, fermentation and microbial population in the rumen of growing lambs. Livestock Science, v.129, p.56-62, 2010.

MARTIN C.; ROUEL J.; JOUANY, J.P. et al. Methane output and diet digestibility in response to feeding dairy cows crude linseed, extruded linseed, or linseed oil. Journal of Animal Science, v.86, p.2642-2650, 2008.

MARTIN, S.A.; NISBET, D.J.; DEAN, R.G. Influence of a commercial yeast supplement on the in vitro ruminal fermentation. Nutrition and Reproduction International, v.40, p.395, 1989.

MARTIN, S.A.; STREETER, M.N. Effect of malate on in vitro mixed ruminal microorganism fermentation. Journal of Animal Science, v.73, p.2141-2145, 1995.

MARTIN, S.A.; STREETER, M.N.; NISBET, D.J. et al. Effects of DL-malate on ruminal metabolism and performance of cattle fed a high-concentrate diet. Journal of Animal Science, v.77, p.1008-1015, 1999.

MAY, C.; PAYNE, A.L.; STEWART, P.L. et al. A delivery system for agents. International Patent Application No. PCT/AU95/ 00733, 1995.

MCCRABB, G.J.; BERGER, K.T.; MAGNER, T. et al. Inhibiting methane production in Brahman cattle by dietary supplementation with a novel compound and the effects on growth. Australian Journal of Agricultural Research, v.48, p.323-329, 1997.

McCRABB, G.J. The relationship between methane inhibition, feed digestibility and animal production in ruminants. In: METHANE
MITIGATION INTERNATIONAL CONFERENCE, 2., 2000, Novasibirsk, Russia. Proceedings... Novasibirsk, 2000. p.125-131.

MIN, B.R.; BARRY, T.N.; ATTWOOD, G.T. et al. The effect of condensed tannins on the nutrition and health of ruminants fed fresh temperate forages: a review. Animal Feed Science and Technology, v.106, p.3-19, 2003.

MONTENY, G.J.; BENNINK, A.; CHADWICK, D. Greenhouse gas abatement strategies for animal husbandry. Agriculture ecosystems \& Environment, v.112, p.163-170, 2006.

MÜNGER, A.; KREUZER, M. Absence of persistent methane emission differences in three breeds of dairy cows. Australian Journal of Experimental Agriculture, v.48, p.77-82, 2008.

O'KELLY, J.C.; SPIERS, W.G. Effect of monensin on methane and heat productions of steers fed Lucerne hay. Australian Journal of Agriculture Research, v.43, p.1789-1793, 1992.

PINARES-PATIÑO, C.S.; ULYATT, M.J.; LASSEY, K.R. et al. Persistence of differences between sheep in methane emission under generous grazing conditions. The Journal of Agricultural Science, v.140, p.227-233, 2003.

RAMASWANY, V.; BOUCHER, O.; HAIGH, J. et al. Report of the intergovernmental panel on climate change. Cambridge: Cambridge University Press, 2001. p.349-416.

RAMIREZ-RESTREPO; BARRY, T.N. Alternative temperate forages containing secondary compounds for improving sustainable productivity in grazing ruminants. Animal Feed Science and Technology, v.120, p.179-201, 2005.

RAUN, A.P.; COOLEY, C.O.; POTTER, E.L. et al. Effect of monensin on feed efficiency of feedlot cattle. Journal of Animal Science, v.43, p.670-677, 1976.

SOLOMON, S.; QIN, D.; MANNING, M. et al. Report of the intergovernmental panel on climate change. Cambridge: Cambridge University Press, 2007.

TIEMANN, T.T.; LASCANO, C.E.; KREUZER, M. et al. The ruminal degradability of fibre explains part of the low nutritional value and reduced methanogenesis in highly tanniniferous tropical legumes. Journal of the Science of Food and Agriculture, v.88, p.1794-1803, 2008.

Van NEVEL, C.; DEMEYER, D. Control of rumen methanogenesis. Environment Monitoring. Assessment, v.42, p.73-97, 1996.

WAGHORN, G.C.; WOODWARD S.L.; TAVENDALE M. et al. Inconsistencies in rumen methane production- effects of forage composition and animal genotype. International Congress Series, v.1293, p.115-118, 2006.

WALLACE R.J.; NEWBOLD, C.J. Rumen fermentation and its manipulation: the development of yeast cultures as feed additives. In: ALLTECH'S ANNUAL SYMPOSIUM, 9., 1993, USA. Proceedings... 1993. p.173-192.

WHEELER, D.M.; LEDGARD, S.F.; de KLEIN, C.A. Using the overseer nutrient budget model to estimate on-farm greenhouse gas emissions. Australian Journal of Experimental Agriculture, v.48, p.99-103, 2008.

WOODFIELD, D.R; EASTON, H.S. Advances in pasture plant breeding for animal productivity and health. New Zealand Veterinary Journal, v.52, p.300-310, 2004.

WOODWARD, S.L.; WOODWARD, G.C.; WAGHORN, G. et al. Early indications that feeding lotus will reduce methane emissions from ruminants. Proceedings of the New Zealand Society of Animal Production, v.61, p.25-36, 2001.

WOODWARD, S.; WAGHORN, G.C.; THOMSON, N.A. Supplementing dairy cows with oils to improve performances and reduce methane - Does it work? Proceedings of the New Zealand Society of Animal Production, v.66, p.176$181,2006$. 